\section{Horsepower from a horse}

SIR - Recent studies of flying animals carrying loads ${ }^{1}$ and of skeletal muscle in vitro subject to cyclic motion ${ }^{2}$ suggest that the maximum sustainable mechanical power per $\mathrm{kg}$ of muscle is $100-200 \mathrm{~W}$. Given an animal's size and its proportion of muscle mass, it is thus possible to calculate an upper limit to an animal's power output. This led us to wonder how much horsepower one horse can actually produce.

The body mass of horses varies from less than $100 \mathrm{~kg}$ for ponies to more than $800 \mathrm{~kg}$ for large draught animals. According to Munro $^{3}$, skeletal muscle for a horse is about 45 per cent of the total mass, but we estimate that only 30 per cent could be used for mechanical work at any one moment. Assuming a mass-specific rate of $100 \mathrm{~W} \mathrm{~kg}^{-1}$ of muscle and a body mass of $600 \mathrm{~kg}$, one horse could, in theory, produce $18,000 \mathrm{~W}$ or, since one horsepower (HP) equals $746 \mathrm{~W}$, about $24 \mathrm{HP}$ ! Is is possible that one horse generates that much horsepower? The assumptions, in the worst case, might inflate the result by a factor of 2, yet this still gives an estimate of about $12 \mathrm{HP}$. This raises the question: was the definition of horsepower based on a lower rate of work, or can a healthy horse actually produce more than $10 \mathrm{HP}$ ?

As to the first possibility, it was James Watt himself who defined horsepower. According to Dickinson ${ }^{4}$, in the early 1780 s Boulton and Watt were manufacturing rotary steam engines that replaced horse gins. Quite naturally, payment for the engine was an annual premium based on the number of horses needed to do the equivalent amount of work. In discussions with millwrights, Watt learned that during a day's work a horse would walk an average of two and a half times per minute around a $24-\mathrm{ft}$ diameter mill wheel. Dickinson $^{4}$ (p. 145) says Watt assumed a horse exerted a tractive effort of 180 pound force (lbf), yielding a power estimate of 33,929 $\mathrm{ft}-1 \mathrm{bf} \mathrm{min}^{-1}$ (power $=$ force $\times$ distance/time). In Watt's blotting and calculation book this number was rounded to $33,000 \mathrm{ft}-\mathrm{lbf} \mathrm{min}^{-1}$, equivalent to the more familiar definition for HP of $550 \mathrm{ft}-1 \mathrm{lbf} \mathrm{s} \mathrm{s}^{-1}$. (The US Bureau of Standards ${ }^{5}$ gives a different account of Watt's calculation

\footnotetext{
1. Ellington, C. P. J. exp. Biol. 160, 71-91 (1991)

2. Stevenson, R. O. \& Josephson, R. K. J. exp. Biol. 149 61-78(1990)

. Munro, H. N. (ed.) in Mammalian Protein Metabolism 133-182 (Academic, New York, 1969).

4. Dickinson, H. W. James Watt (David \& Charles, Newton Abbot, 1967).

5. US Dept. of Commerce Cir. Bureau Stand. 34 (1912)

6. Collins, E. V. \& Caine, A. B. lowa Agri. exp. Sta. Bull. 240 193-223(1926)

7. Vandewaile, H., Peres, G., Heller, J., Panel, J. \& Monod, H. Eur. J. appl. Physiol. 56, 650-656 (1987).

8. Youatt, W. The Horse (Knight \& Co, London, 1846)

9. Drent, R. H. \& Daan, S. Ardea 68, 225-252 (1980).

10. Peterson, C.C., Nagy, K. A. \& Diamond, J. Proc. natn Acad. Sci.U.S.A. 87, 2324-2328(1990).
}

that says he considered engine friction.) By either calculation, Watt's measure of power output is clearly based on a rate that horses could maintain for a full day, not a peak performance.

As to the second possibility, Collins and Caine $^{6}$ list data from the horse pulling contest at the 1925 Iowa State Fair showing that peak mechanical power output of a horse is 12-14.9 HP. This effort lasted only a matter of seconds and is probably a realistic estimate of peak performance. Similar maximal rates, when expressed per $\mathrm{kg}$ of body mass, have been documented in human athletes ${ }^{7}$.

Why is the daily work rate so much lower? Collins and Caine ${ }^{6}$ suggest that a draught horse should pull 10 per cent of its body weight at a rate of $2.5-3$ miles $h^{-1}$ (10-hour working day) to maintain health

\section{Hox genes, fin folds and symmetry}

SIR - Tabin and Laufer ${ }^{1}$ suggest an evolutionary explanation of the similarity between tetrapod fore and hind limbs in which the Hox gene-regulated limb pattern originated in the pelvic appendage, and subsequent ectopic activation imposed the regulation and resultant homeotic transformation on the ancestral pectoral fin/fore limb. I agree with the

general proposal that patterns of genetic regulation provide a new level of explanation for homology $y^{2}$, but I question Tabin and Laufer's specific evolutionary hypothesis.

The 'pelvic before pectoral limb' evolutionary model is based partly on the continuous lateral fin-fold theory of the origin of paired vertebrate appendages,
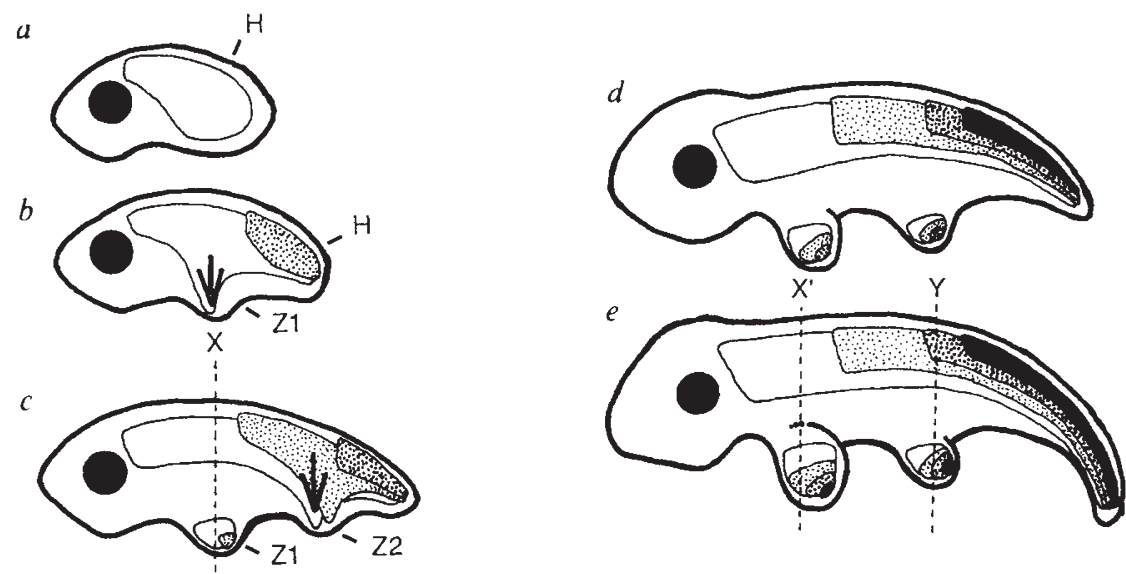

Schematic representation of spatial and temporal (a-e) sequential overlapping Hox gene expression domains in a developing vertebrate embryo (from refs 2,8 in ref. 1). Black dot, cranial region; arrows, mesoderm migrating laterally into emergent limb bud; thin outlines delimit Hox gene expression domains in limb buds and trunk/caudal regions (shaded from clear, stippled to black). Maintenance and elaboration of Hox gene expression along cranio-caudal and limb-outgrowth axes appears to be influenced by a unified system ${ }^{14}$ in which signalling activity emerges from centre $\mathrm{H}$, and spreads into flank tissue centres $Z 1$ and $Z 2$ (ref. 14), with peak activity occurring in pectoral before pelvic limb fields. At an early stage (c). Hox gene expression in the pectoral limb bud mesoderm resembles that in the axial mesoderm (section $X$ ) because the former is derived from the latter. At a later state $(e)$ increased dissimilarity between the expression patterns (section $X^{\prime}$ ) results from the fixed anterior position and continued distal development of the pectoral limb bud, and the elaboration of trunk Hox gene expression in more posterior axial mesoderm. Initiation of the pelvic limb bud at a later stage incorporates posterior axial mesoderm in which a fulier complement of Hox genes has either already been or will be expressed. Position in the posterior flank region leads to closer similarity of expression pattern with adjacent mesoderm (section $\mathrm{Y}$ ). As the activity of $\mathrm{Z1}$ peaks before $\mathrm{Z2}$ during ontogeny, a similar sequence is argued to have occurred in phylogeny. Contrary to the suggestion in ref. 1 , no homeotic transformations, translations of signalling centres between fins, taxa with continuous lateral fin folds or with pelvic but without pectoral fins ${ }^{3}$, are required. However, differences remain between the Hox expression patterns predicted by this alternative hypothesis and those few which are actually known. Here, anterior-most genes expressed axially have principal expression in the limb buds, followed by the remainder of the Hox network, whereas in known amniote limb buds only the posterior members of clusters $A$ and $D$ of the Hox network are expressed. 